\title{
Medical Students Perception about Doctor's Body Image Using Stunkard Figure Rating Scale (FRS) Method
}

\author{
Agustina Arundina Triharja Tejoyuwono ${ }^{1}$, Muhammad Riedha ${ }^{2}$ \\ ${ }^{1}$ Public Health Department, Tanjungpura University, Indonesia \\ ${ }^{2}$ Anatomy Department, Tanjungpura University, Indonesia
}

\section{Article Info \\ Article history: \\ Received Aug 16, 2015 \\ Revised Sep 19, 2015 \\ Accepted Oct 16, 2015}

\section{Keyword:}

Doctor's body image

Medical students

Perception

Stunkard frs

\begin{abstract}
Doctor as health workers are obliged to be role models, especially in healthy and active life style projected as having an ideal body image. It beneficial to increase self confidence, improve sucess in counceling and health service satisfaction and as well as gaining patient's trust. Body image sometimes considered unnecessary, however it could be quite disturbing in health service. This research used descriptive survey study with quantitative data. A total of 576 medical students were enrolled in this research, they are from medical, pharmacy and nursing grade 2011 to 2014. Triangulation data collected from 16 doctors working in medical school, and 7 doctors from Tanjungpura University Hospital. Sample was choosen by purposive sampling and analyzed by descriptive statistic. As many $93.06 \%$ of respondents stated that body image is important for doctor and it will influence the theraphy. $67.2 \%$ chose picture 4 (normal nutritional status) in Stunkard Figure Rating Scales the ideal body images for doctors. Nevertheless, $17.01 \%$ choose picture $<3$ (underweight) and $15.8 \%$ choose picture $>5$ (overweight and obesity) as the doctor's ideal body images. Doctors that work in Educational field were the most important field that needs a good body image (42.88\%), followed by doctor in hospital (24.83\%). Based on triangulation data, suggested that body image will not impact the therapy (82.6\%) and the most important field that needs ideal body images was in hospital (43.5\%). Body image is very important and it will influence doctor theraphy. Doctor in educational field should have an ideal body image with normal nutrition status.
\end{abstract}

Copyright (C) 2015 Institute of Advanced Engineering and Science. All rights reserved.

\section{Corresponding Author:}

Agustina Arundina Triharja Tejoyuwono,

Public Health Department,

Tanjungpura University,

Jl. Prof. Dr. Hadari Nawawi, Pontianak, West Kalimantan, Indonesia.

E-mail : ina.tejo@gmail.com

\section{INTRODUCTION}

The prevalence of obesity and overweight cases keep increasing every year [1]. At an estimated $73 \%$ of health workers suffer from obesity and overweight [2], where $44.4 \%$ of them are women and $7.9 \%$ are men. This data is supported from a research conducted by Abbate et al., [3] which showed13.6\% of women and13.3\% men suffered from obesity and overweight. Research done by Nunez et al., [4] showed that the female health workers are more at risk of suffering from obesity and overweight by $75 \%$ than men.

Body image is physical appearance associated with body weight, which assessed in at least three separate components of the body image that are the perception of body size, the components of subjective and behavioral aspects that will determine the results of the subjective assessment [5]. Body image from a health perspective is still considered to be a sensitive issue [6]. 
Body image could reflect the health status of a person, while for health personnel, body image may portrayed professionalism, could increase the positive relationship between counselor and client and the success in providing therapy especially for body weight control [7]. Hartati and Darmarini [8] conducted a research on the nutritionists suggested that body image will determine the quality of nutrition services to be provided, especially in the provision of direct evidence (tangibles) and guarantees (assurance).

Health worker is regarded as a role model, especially as a form of good medical image that has good impact to the community.Although this issue remains sensitive to talk about, however, the results of the study found that awareness of health personnel of good body image will affect health worker empathy on issues related to the patient's body shape [9],[10].

Therefore, this study aims to analyze the assessment of body image of the doctors with Stunkard Figure Rating Scale to the students of the Faculty of Medicine, University of Tanjungpura and also to describe the results of the importance of body image to the doctors, the effect of body image to the therapy and doctor's field of work that requires body image and also to compare the perception of physicians' body image between Medical students, Pharmaceutical students and Nursing students in the Faculty of Medicine University of Tanjungpura.

\section{RESEARCH METHOD}

\subsection{Ethical Clearance}

The ethics approval has been issued by the Division of Ethics Review of the Faculty of Medicine with registration no.3986/UN22.9/DT/2014. Data collected from the subject was anonymously meaning that does not include the name of the subject only using the code describing study program and students' number. All data is confidential and will not be disseminated. The research does not give rewards/any intervention to the subject, because it is voluntary.

\subsection{The Study Design and Subject}

The study design used is descriptive survey with quantitative data. Subjects in this study were students of the Faculty of Medicine class of 2011 to 2014 at the University of Tanjungpura. Triangulation of data was done on professional doctors who work in the Faculty of Medicine of University of Tanjungpura and Tanjungpura University Hospital. The sample selection using purposive non-probability sampling, in which the subject criteria are willing to participate in the study and not being an academic leave.

The collection of data were done by using a closed question questionnaire consisting of 3 questions concerning the subjects' opinion about the importance of body image for doctors; the effect on the doctor's treatment; and the field of jobs which are most in need of a goodbody image. The questionnaire also included Figure Rating Scale (figure 1) which is developed by Stunkard et al (1983). Score 4 is an idealized image in Stunkard figure rating scale based on where the limit of $50 \%$ of normal weight, and score $<=3$ shows the nutritional status of underweight whereas score $>=5$ is the limitation of nutritional status overweight to obese [11].

Results of the study will be illustrated in the form of tables and graphs using univariate and the comparison between students and general practitioners will be shown in the table. The collection of data carried out since September $22^{\text {nd }}$, 2014 until October 6th, 2014 by distributing questionnaires.

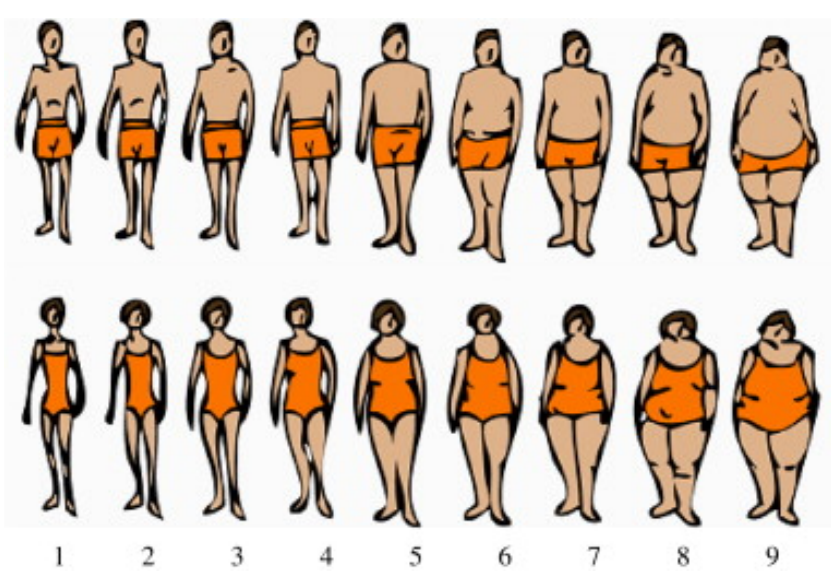

Figure 1. Body Shape Figures Scale [12] 


\section{RESULTS AND ANALYSIS}

The total subjects in this research were 576 students from three study programs at the Faculty of Medicine,which consists of 268 students of Medicine ranging from class of 2011 to 2014, 160 students of Pharmacy ranging from class of 2012-2014 and 148 students of Nursing ranging from class of 2012-2014. While the subject of triangulation obtained was from 16 doctors who worked at the Faculty of Medicine and 7 doctors who worked at the Tanjungpura University Hospital.

\subsection{The Importance of Body Image to Doctors}

Figure 2 shows the proportion of subjects who consider the importance of body image to the doctors. Evidently as much as $93.06 \%$ of the total subjects stated that body image is very important to the doctor and only 6.94\% said that the doctor's body image is not important. Apparently, nursing students are the highest with $97.3 \%$ stated that body image is important. On the other hand, medical students found to be the highest stating that body image is not important to the doctors with a value of $9.7 \%$ although $90.3 \%$ still stated that body image is important. This assessment can be seen in Figure 2.

\section{- Important $\quad$ Not Important}

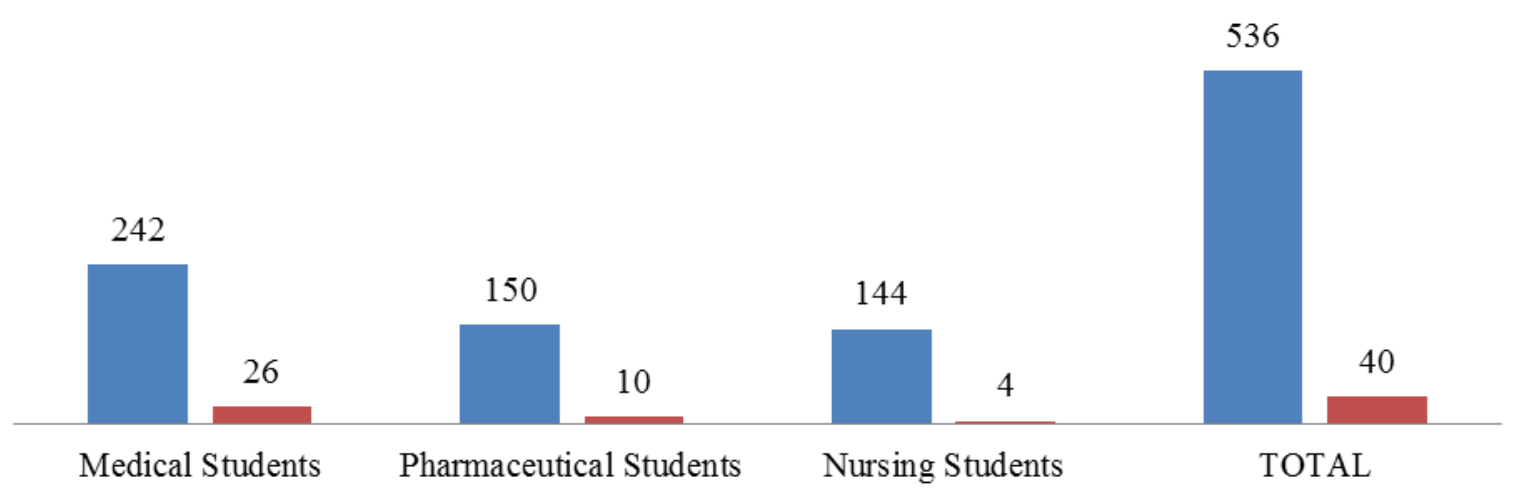

Figure 2.Bar Diagram of The Importance of Body Images to Doctors

\subsection{The Effect of Body Image to The Therapy Given}

Based on the results of the assessment of the student view of the effects of body image to the therapy provided by physicians have quite varied answers. Of all students, there is a 53.99\% stated that body image will affect the therapy, and the remaining $46.01 \%$ of the subjects stated body image will not affect the treatment given. The difference of the two is $7.99 \%$.

As many as $51.1 \%$ of medical students stated that the therapy will not be affected from the doctors'body image, however, approximately $67.6 \%$ of nursing students expressed that the therapy given by the doctor will be affected by body image. While the Pharmacy students suggested the same view regarding the effect of body image to the therapy administered. A clearer picture can be seen in Figure 3.

\section{Effected $\quad$ Not Effected}

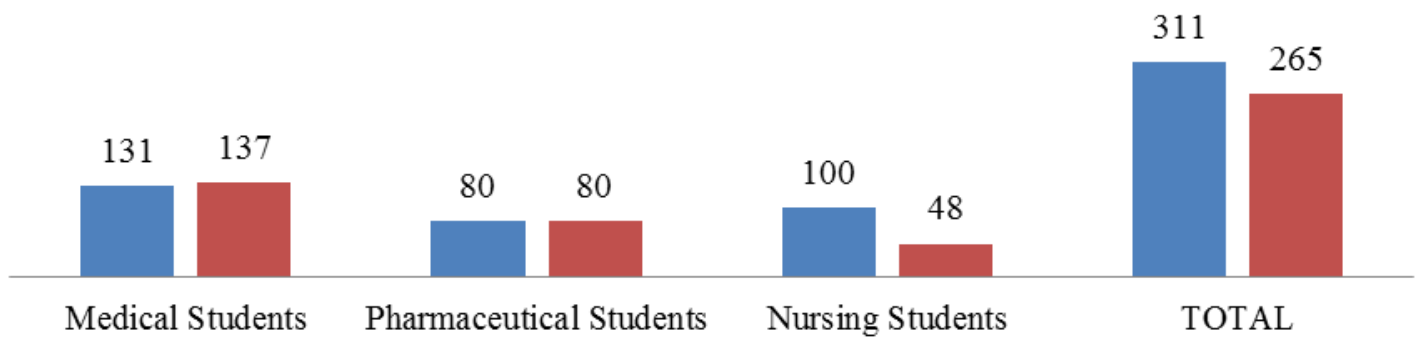

Figure 3. Bar Diagram of The Effect of Body Image to The Therapy Given 


\subsection{Body Image with Stunkard Figure Rating Scale}

Assessment using Stunkard Figure Rating Scale, showed a fluctuating response to of the answers regarding the doctor's body shape. In general, $67.2 \%$ of students stated that the figure 4 is the ideal body image. However, the number of students who give a negative assessment of the body imaging physicians are also quite a lot. There are as many as $17.01 \%$ stated that the ideal body image is underweight with a choice of image $<3$, and the remaining $15.8 \%$ said that the ideal body image doctor who is overweight-obese with a picture of $>5$.

Physicians' normal body image is often stated mostly by $70.9 \%$ nursing students, followed by 66.4\% medical students and $65.0 \%$ Pharmaceutical. On the other hand, negative imaging of the body most often mentioned by medical student (21.6\%) where they portray doctors underweight, followed by nursing $14.2 \%$ and $11.9 \%$ Pharmaceutical. Image of overweight and obesity was often raised by students of Pharmacy with 23.1\%, followed by Nursing and Medical 14.8\% and 11.9\%.

Tabel 1. Body Image with Stunkard Figure Rating Scale (FRS)

\begin{tabular}{cccc}
\hline \multirow{2}{*}{ Criteria of FRS } & $\begin{array}{c}\text { Medical } \\
\text { Students }\end{array}$ & $\begin{array}{c}\text { Pharmaceutical } \\
\text { Students }\end{array}$ & $\begin{array}{c}\text { Nursing } \\
\text { Students }\end{array}$ \\
\cline { 2 - 4 } & $\mathrm{N}$ & $\mathrm{N}$ & $\mathrm{N}$ \\
\hline 1 & 1 & 0 & 0 \\
2 & 2 & 1 & 0 \\
3 & 55 & 18 & 21 \\
4 & 178 & 104 & 105 \\
5 & 31 & 36 & 20 \\
6 & 1 & 0 & 2 \\
9 & 0 & 1 & 0 \\
\hline
\end{tabular}

\subsection{Physicians' Field of Work That Needs Body Image}

Based on the field work of doctors, is divided into four sections, namely Education, Health Center, Hospital and public services in relation to body image. According to students' suggestions, field of work that needs a good body image is in the field of education with $42.88 \%$, followed by the Hospital with $24.83 \%$. However, field of work that require less important body image is a doctor in the public service, namely 42.19\%, 36.81\%, followed by public health centers.

Doctors who work in the field of education are required to have good body image, where $42.88 \%$ of the students responded that it is very important, although, $25.52 \%$ of students also answered less important to have a good body image. While doctors who work in the hospital suggested that it was important and crucial need of body image (37.50\%; 24.83\%).

In the field of health centers and public services, the response was nearly balanced, where both are suggested quite important; important to the value of 36.81; 32.64 at health centers and 21:01; 20:49 on public services. Distribution of student assessment can be seen in Table 2 below.

Based on the Table 2 above, the medical students stated that education is the area for a doctor that need good body image (44.8\%), followed by the work of doctors in the hospital (38.8\%) and health centers (35.4\%).The answer is almost the same as the student of nursing where $52.7 \%$ said education is the most important need of body image, followed by hospitals and a significant $33.1 \%$ on $41.9 \%$ of doctors in the health center.

Another statement is suggested by Pharmacy students who stated that doctors' field of work that need a good body image mostly is in hospital with $39.4 \%$. In the area of public health centers also considered important enough to have a good body image by $48.8 \%$. While work that suggested as the least important to have good body image is in general service with a value of 47.0\%; 43.9\%; 32.5\% (Medical Student; Nursing; Pharmacy). 
Tabel 2. Distribution Physicians’ Field of Work That Needs Body Image

\begin{tabular}{|c|c|c|c|c|}
\hline \multirow[t]{17}{*}{ Medical Students } & \multirow[t]{5}{*}{ Education } & Kategori & $\mathrm{N}$ & $\%$ \\
\hline & & Very important & 120 & 44.8 \\
\hline & & Important & 20 & 7.5 \\
\hline & & Quite important & 83 & 31 \\
\hline & & Less important & 45 & 16.8 \\
\hline & \multirow[t]{4}{*}{ Health Center } & Very important & 59 & 22 \\
\hline & & Important & 95 & 35.4 \\
\hline & & Quite important & 72 & 26.9 \\
\hline & & Less important & 42 & 15.7 \\
\hline & \multirow[t]{4}{*}{ Hospital } & Very important & 58 & 21.6 \\
\hline & & Important & 104 & 38.8 \\
\hline & & Quite important & 51 & 19 \\
\hline & & Less important & 55 & 20.5 \\
\hline & \multirow[t]{4}{*}{ Public Services } & Very important & 32 & 11.9 \\
\hline & & Important & 49 & 18.3 \\
\hline & & Quite important & 61 & 22.8 \\
\hline & & Less important & 126 & 47 \\
\hline Pharmaceutical & \multicolumn{4}{|l|}{ Education } \\
\hline \multirow[t]{16}{*}{ Students } & & Very important & 49 & 30.6 \\
\hline & & Important & 21 & 13.1 \\
\hline & & Quite important & 25 & 15.6 \\
\hline & & Less important & 65 & 40.6 \\
\hline & \multirow[t]{4}{*}{ Health Center } & Very important & 21 & 13.1 \\
\hline & & Important & 42 & 26.3 \\
\hline & & Quite important & 78 & 48.8 \\
\hline & & Less important & 19 & 11.9 \\
\hline & \multirow[t]{4}{*}{ Hospital } & Very important & 44 & 27.5 \\
\hline & & Important & 63 & 39.4 \\
\hline & & Quite important & 29 & 18.1 \\
\hline & & Less important & 24 & 15 \\
\hline & \multirow[t]{4}{*}{ Public Services } & Very important & 46 & 28.8 \\
\hline & & Important & 34 & 21.3 \\
\hline & & Quite important & 28 & 17.5 \\
\hline & & Less important & 52 & 32.5 \\
\hline \multirow[t]{16}{*}{ Nursing Student } & \multirow[t]{4}{*}{ Education } & Very important & 78 & 52.7 \\
\hline & & Important & 14 & 9.5 \\
\hline & & Quite important & 19 & 12.8 \\
\hline & & Less important & 37 & 25 \\
\hline & \multirow{4}{*}{ Health Center } & Very important & 13 & 8.8 \\
\hline & & Important & 51 & 34.5 \\
\hline & & Quite important & 62 & 41.9 \\
\hline & & Less important & 22 & 14.9 \\
\hline & Hospital & Very important & 41 & 27.7 \\
\hline & & Important & 49 & 33.1 \\
\hline & & Quite important & 35 & 23.6 \\
\hline & & Less important & 23 & 15.5 \\
\hline & Public Services & Very important & 16 & 10.8 \\
\hline & & Important & 35 & 23.6 \\
\hline & & Quite important & 32 & 21.6 \\
\hline & & Less important & 65 & 43.9 \\
\hline TOTAL & Education & & & \\
\hline & & Very important & 247 & 42.88 \\
\hline & & Important & 55 & 9.55 \\
\hline & & Quite important & 127 & 22.05 \\
\hline & & Less important & 147 & 25.52 \\
\hline & Health Center & Very important & 93 & 16.15 \\
\hline & & Important & 188 & 32.64 \\
\hline & & Quite important & 212 & 36.81 \\
\hline & & Less important & 83 & 14.41 \\
\hline & Hospital & Very important & 143 & 24.83 \\
\hline & & Important & 216 & 37.50 \\
\hline & & Quite important & 115 & 19.97 \\
\hline & & Less important & 102 & 17.71 \\
\hline & Public Services & Very important & 94 & 16.32 \\
\hline & & Important & 118 & 20.49 \\
\hline & & Quite important & 121 & 21.01 \\
\hline & & Less important & 243 & 42.19 \\
\hline
\end{tabular}

IJPHS Vol. 4, No. 4, December 2015 : $294-303$ 


\subsection{The Comparison between The Assessment of Students' and Professional}

Assessment of body image by student and physicians have some differences.Among them is the effects of body image to the therapy given by the doctors.As many as $54 \%$ of students stated that body image will influence the outcome of therapy to be administered by a doctor, but $82.6 \%$ of physicians did not agree with the statement.It also occurs in the field of work affecting body image, which according to the respondents, the doctors in the education area are very important to have a good body image (42.9\%), but according to doctors, doctors who work in the hospital are more important to have a good body image (43.5\%).

Surprisingly both respondents suggested the same thing about the importance of body image to the doctor (93.1\%; 95.7\%).Both groups also provide the same option on the imaging body good doctor according to Figure Rating Scale, namely in figure 4 (67.2\%; 69.6\%). While the area of public service, both groups agreed that they need less important good body image (42.2\%; 65.2\%).

Based on data in Table 2, it is known that they found a negative assessment of the physician imaging both the student and doctor.17.4\% of doctors choose a picture showing the three FRS body image underweight, and $13.0 \%$ chose overweight body image (image 5 FRS) as the body image of the good doctor.It also happens to students, $17 \%$ chose a picture underweight, and $15.8 \%$ chose overweight picture as the ideal body image doctor. More details can be seen in Table 3.

Tabel 3. Tabel of The Comparison between The Assessment of Students’ and Professional

\begin{tabular}{|c|c|c|c|c|c|}
\hline \multirow{2}{*}{ Questions } & & \multicolumn{2}{|c|}{ Students } & \multicolumn{2}{|c|}{ Professional Doctors' } \\
\hline & & $\mathrm{N}$ & $\%$ & $\mathrm{~N}$ & $\%$ \\
\hline \multirow[t]{2}{*}{ Importance of Body Image } & Important & 536 & 93.1 & 22 & 95.7 \\
\hline & Not Important & 40 & 6.9 & 1 & 4.3 \\
\hline \multirow{2}{*}{$\begin{array}{l}\text { Effect of Body Image to The } \\
\text { Theraphy Given }\end{array}$} & Effected & 311 & 54.0 & 4 & 17.4 \\
\hline & Not Effected & 265 & 46.0 & 19 & 82.6 \\
\hline \multirow{7}{*}{$\begin{array}{l}\text { Body Image Picture With Stunkard } \\
\text { Figure Rating Scale }\end{array}$} & 1 & 1 & 0.2 & 0 & 0.0 \\
\hline & 2 & 3 & 0.5 & 0 & 0.0 \\
\hline & 3 & 94 & 16.3 & 4 & 17.4 \\
\hline & 4 & 387 & 67.2 & 16 & 69.6 \\
\hline & 5 & 87 & 15.1 & 3 & 13.0 \\
\hline & 6 & 3 & 0.5 & 0 & 0.0 \\
\hline & 9 & 1 & 0.2 & 0 & 0.0 \\
\hline \multicolumn{6}{|c|}{ Physicians’ Field of Work That Needs Body Image } \\
\hline \multirow[t]{4}{*}{ Education } & Very important & 247 & 42.9 & 7 & 30.4 \\
\hline & Important & 55 & 9.5 & 5 & 21.7 \\
\hline & Quite important & 127 & 22.0 & 9 & 39.1 \\
\hline & Less important & 147 & 25.5 & 2 & 8.7 \\
\hline \multirow[t]{4}{*}{ Health Center } & Very important & 93 & 16.1 & 7 & 30.4 \\
\hline & Important & 188 & 32.6 & 7 & 30.4 \\
\hline & Quite important & 212 & 36.8 & 5 & 21.7 \\
\hline & Less important & 83 & 14.4 & 4 & 17.4 \\
\hline \multirow[t]{4}{*}{ Hospital } & Very important & 143 & 24.8 & 7 & 30.4 \\
\hline & Important & 216 & 37.5 & 10 & 43.5 \\
\hline & Quite important & 115 & 20.0 & 4 & 17.4 \\
\hline & Less important & 102 & 17.7 & 2 & 8.7 \\
\hline \multirow[t]{4}{*}{ Public Services } & Very important & 94 & 16.3 & 2 & 8.7 \\
\hline & Important & 118 & 20.5 & 1 & 4.3 \\
\hline & Quite important & 121 & 21.0 & 5 & 21.7 \\
\hline & Less important & 243 & 42.2 & 15 & 65.2 \\
\hline
\end{tabular}

\subsection{Discussion}

There are about $73 \%-75 \%$ of workers both men and women who work in the health care sector are overweight and obese [2]-[4] and cases of obesity on health workers are estimated to continue to increase in the future [13]. In the study by Lara et al., [14] found that the incidence of physicians and patients that have abdominal obesity is quite the same, and suggested that doctors are more likely to suffer from cardiovascular disease. The persistently high incidence of obesity, especially in the doctor has become a hot topic for investigation. This is precisely what brings researchers conducted a study that aims to determine a picture of the perception of body image of a doctor. Researchers trying to get an overview of potential perpetrators health workers from student at the Faculty of Medicine, University Tanjungpura consisting of students of 
medicine, nursing and pharmacy. Their opinion will determine the quality of a doctor and a view of health workers.

In the study conducted by Goswami et al., [15] in a new class of 96 female students in 2012 in India, found that $83.33 \%$ said their body image is good to very good and satisfied with their image. Furthermore, a study conducted at an educational institution in Israel by Korn, et al., [16] explored a relationship between self-perception and healthy body image perception of the 1574 undergraduate students. Significant results reported that the male student was found higher than female students in terms of healthy perception and the perception of the body and self-image. Most female students tend not satisfied with their body image [2]. Dissatisfaction with body image also happens to health workers in Tehran, where they perceive themselves to have more weight. These misperceptions mainly occur in women with normal BMI than women who are obese / overweight [17].

Although the method is slightly different from both of these studies, notably similarity is that most students consider a good body image could give more satisfaction for themselves. In association with the data in this study, the satisfaction with self body image will further makes it important to note.

In this study it was found that the majority of students and professional doctors as much as $93.1 \%$ and $95.7 \%$ stated that body image is important for the doctor. Weight and health status affects the perception of the patient's physician regarding health counseling by doctors [18]. If a doctor has a good health condition, the advice given by the doctor is considered more credible, to further increase motivation and reliable [19]. This statement is supported by Bleich et al., [20] suggested that the trust of patients to doctors will decrease if the doctor is overweight or obese. Moreover, they would be considered less convincing while treating the patients in regards of lifestyle changes. Bleich also stated that physicians understand and realize that they should become a role model of health. However, according to Armour [21] physical appearance of employees in the workplace, whether working in the health field or not, have an enormous influence on the success story in the work and trust in the competence of health personnel.

Although good body image of a doctor is regarded as important to the majority but this has not been an absolute $100 \%$ essential. There are still $6.9 \%$ and $4.2 \%$ of students' professional doctors who think it is not important. This is due to the ability of physicians to provide motivation communication and dietary recommendations remain an important thing that will affect the success of diet therapy [20]. This is reinforced by the results found by Puoane et al., [22] of the 44 black women health workers in one city in South Africa. Data show that 40 people out of 44 found in the category of obese and overweight category 2. Based on focus group discussions conducted in the study, most of the women stated that the shape of the body of a person shall in a 'fuller' and 'curvy' image and anyone can have a body shape like that and still be able to complete the work given to him.

Regarding the effect of body image on the treatment given to the patient, the students thought that the body image will affect the treatment given at approximately 54\% of the respondents. Hash et al.,[18] reported that patients will be looking more health services from doctors that non-obese. These results are also consistent with the data presented by Puhl et al., [23] that perception of body image who are overweight or obese are prone to get biased attitude from the patient. Excessive weight gain by health care providers or doctors can negatively affect patients' perceptions in terms of credibility; confidence level and a tendency to follow medical advice.

Look deeper and specific about the service management of obesity, the patient still consider physicians with good and healthy body image can provide appropriate health advice. If the doctor is in a healthy image, the advice given will be felt credible, motivated, and reliable. These results are consistent with previous research by Fraser et al., [19] who concluded that the weight and health status of a doctor could potentially impact on the perception of health advice. Patient's trust is indicated higher when getting advice from a doctor that the non-obese.

Instead there is as much as $46 \%$ still think it is not giving impact in the therapy management. These data reinforced by the triangulation data obtained reported that $82 \%$ doctors believe that the response will not affect the body image therapy given to patients. Body image is not the main thing in clinical aspect. This issue is very interesting due to the study report conducted by Bleich et al., [24] stated that in general the overweight and obese patients will continue to trust the doctor's care and treatment without being affected by body image of the doctor. More specifically, the study found that the patients will have more confidence in advice for diet or weight control from doctors who are overweight or obese when compared with physicians who non overweight. So the stigma is thought that the therapy can be affected by body image owned by doctors not proven significantly.

Another study suggested that patients will feel annoyed and could negatively affect the treatment that is given if the doctor did not pay full attention to the problems they experienced. Several factors put forward is that patients often find a doctor who does not show sufficient engagement with the patient; sufficient knowledge of obesity treatment services; and leave the responsibility for providing adequate 
information about available referral. It can be concluded therapeutic failure is more influenced by the attitude and attention by doctors to their patients as reported in the study by Malterud et al., [25]

Moving onto the ideal body image assessment using the Stunkard Figure Rating Scale, most respondents chose the ideal body image doctor is a doctor with a normal nutritional status. Assessment with the FRS can be used as the basis for determining the supposed prediction of BMI and BMI is the most accurate way to predict a person's body size. Determination using the FRS would give the perception or view of the shape of the body of a doctor and a lot of things that will affect the outcome such as ethnic factors, interest between the sexes, social views and the mass media [26]. Physician-patient relationship is not only a therapy of diseases, but also to the problem disease prevention and settlement of personal problems of patients [27],[28] and it therefore requires a good attitude one is to apply a nourishing life and indicates the correct body image as a role model of health [29].

In the scope of professionalism which requires a good body image of a doctor, our study found that according to doctors in the education is very important to have a good body image (42.9\%), but by professional doctors, hospital doctors work more important needs a good body image (43.5\%), As a doctor working in education, they will be the first image of a doctor for prospective medical students and can affect their view of the future doctors. besides it also as a health educator is expected to provide guidance regarding the true positive outlook in obese patients and overweight [30]. But in the service, the doctor will determine the image of the patient's perception of the quality of life of health workers mainly doctors. The health worker is expected able to provide advice and act as an example to the patient by running healthy living, provide health promotion and disease prevention [2].

\subsection{Study Limitations}

There are some limitations in the analysis of this study. First, the study was a descriptive that can only illustrate the answers of the question given to the subject. The study does not evaluate the relationship between variables. Second, poor level of participation from the students about the importance of the research conducted, thus, it does not portray the total of students in the Faculty of Medicine University of Tanjungpura. Third, the answer bias of the perception, view, rate and expectations of the ideal body image of each individual is not assessed but expected to remain objective results given in accordance with the scientific basis of health which is owned by the students. Fourth, the influence of response to therapy and the workers who require the ideal body image can be affected by the location of educational background, various types of doctors who've seen by students and lack of experience in society that affect the perception of the ideal body image. Latest, the shortages which are expected to occur in this research could be minimized by the sharp analysis and discussion of the results.

\section{CONCLUSION}

This study gives an overview that body image to doctor is important and will affect the treatment given by the doctor. The doctor's ideal body image is who has a normal nutritional status, and doctors who work in health education are expected to have an ideal body image as a role model of health. Further research is needed to get the perception from public and conduct anthropometric examination the doctor compared to the perception and treatment outcome of obesity / overweight given by the doctor.

\section{ACKNOWLEDGEMENTS}

This work has been supported by Medical School Tanjungpura University. We also thank to medical student council, IMKU, HMF and HIMIKAWA, for their supported in collecting data.

\section{REFERENCES}

[1] Roberts, ML., Zonfrillo, MR., Yu, S., Dziura, JD., Spiro, DM., “Overweight physicans during residency: A crosssectional and longitudinal study”, Journal of Gratitude Medical Education, vol/issue: 5(3), pp. 405-11, 2013.

[2] Skall, L., Pengpid, S., "Obesity and health problems among south African healthcare workers: do healthcare workers take care of themselves?”, J South Africa Family Practice, vol/issue: 53(6), pp. 563-7, 2011.

[3] Abbate, C., Giorgianni, C., Munao, F., Beninato, G., D’Arrigo, G., D’Arrigo, P., Brecciaroli, R., “Evaluation of obesity In healthcare workers”, Med Lav, vol/issue: 97(1), pp. 13-9, 2006.

[4] Nunez, NC., Ochoa, VU., Solares, NJC., Solares, CJ., Cardenas, VM., Campos, A., "Overweight and obesity among health-professional woman”, Ginecol Obstet Mex, vol/issue: 73(8), pp. 401-6, 2005.

[5] Heinberg, L., Wood, KC., Thompson, K., "Body Image. In: Rinkert, Vaughn. Adolescent nutrition assasment and management”, Chapmann \& Hall: New York, pp. 136-156, 1995. 
[6] Gila, A., Castro, J., Toro, J., Salamero, M., "Subjective body image dimensions in normal female population: evolution through adolescence and early adulthood”, International Journal of Psychology and Pshchological Theraphy, vol/issue: 4(1), pp. 1-10, 2004.

[7] McArthur, L., Ross, J., "Attitudes of registered dietitians toward personal overweight and overweight clients", Journal of The American Dietetic Association, vol/issue: 97(1), pp. 63-66, 1997.

[8] Hartati, B., Darmarini, F., “Indikator kinerja mutu asuhan gizi dalam pelayanan gizi rumah sakit”, Prosiding ASDI: Pertemuan Ilmiah Nasional Dietetic II, 28-19 Febuari 2005.

[9] Brown, I., Stide, C., Psarou, A., Brewins, L., Thompson, J., "Management of obesity in primary care: Nurses' practices, beliefs and attitudes”, J Adv Nurs, vol. 59, pp. 329-41, 2007.

[10] Wright, J., "Female nurses' perception of acceptable female body size: an exploratory study", J Clin Nurs, vol/issue: 7(4), pp. 307-315, 1998.

[11] Lo, Wing-Sze, Ho, Sai-Yin, Mak, Kwok-Kei, Lam Tai-Hing, “The use of Stunkard’s Figure Rating Scale to identify underweight and overweight in Chinese adolescents”, PLOS ONE, vol/issue: 7(11), pp. 1-5, 2012.

[12] Prevos, P., "Differences in body image between men and woman.Psychology 1A Course (PSY 11)", pp 1-4, 2005. Available from: http://www.prevos.net/body image.htm, [Accessed 24 Mei 2008].

[13] Luckhaupt, SE., Cohen, MA., Li, J., Calvert, G., "Prevalence of obesity among U.S workers a associations with occupational factors”, Am J Prev Med., vol/issue: 46(3), pp. 237-248, 2014.

[14] Lara, A., Meaney, A., Morales, PK., Meaney, E., Juan Asbun-Bojalil, Lucas, CHA., Olivares, I., Ceballos, G., "Frecuencia de obesidad abdominal en medicanos mexicanes de primer cintacto y en sus pacientes", Medicina Interna de Mexico, vol/issue: 23(5), pp. 391-397, 2007.

[15] Goswani, S., Sachdeva, S., Sachdeva, R., "Body image satisfaction among female college students”, Industrial Psychiatry Journal, vol/issue: 21(2), pp. 168-172, 2012.

[16] Korn, L., Gonen, E., Shaked, Y., Golan, M., "Health perceptions, self and body image, physical activity and nutrition among undergraduate students in Israel”, PLOS ONE, vol/issue: 8(3), pp. 1-7, 2013.

[17] Dorosty, AR., Mehdikhani, S., Sotoudeh, G., Rahimi, A., Koohdani, F., Tehrani, P.,’Percepton of weight and health status among woman working at health centre of Tehran”, J Health Pupul Nutr., vol/issue: 32(1), pp. 58-67, 2014.

[18] Hash, RB., Munna, RK., Vogel, Bason, JJ., “Does Physician weight affect perception of health service?”, Prev Med, vol/issue: 36(1), pp. 41-4, 2003.

[19] Frasser, SE., Leveritt, MD., Ball, LE., "Patients' perceptions of their general practitioner's health and weight influences their perceptions of nutrition and exercise advice received", Journal of Primary Health Care, vol/issue: 5(4), pp. 301-307, 2013.

[20] Bleich, SN., Bennett, WL., Gudzune, KA., Cooper, LA., "Impact of physician BMI on obesity care and beliefs", Obesity, vol/issue: 20(5), pp. 999-1005, 2012.

[21] Armour, S., "Your appearance, good or bad, can effect size of your paycheck", USA Today, 2005. Available from: http://www,usatoday.com/educate/college/business/article/20050724.htm. [Accessed 9 Febuari 2009].

[22] Puoane, T., Fourie, JM., Shapiro, M., Rosling L., Tshaka, NC., Oelefse, A.,”'Big is beautiful'- an exploration with urban black community health workers in South African township”, SAJNC, vol/issue: 18(1), pp. 6-15, 2005.

[23] Puhl, RM., Gold, JA., Luedickle, J., Delpierre, JA., “The effect of physicians' body weight on patient attitudes: implications for physician selection, trus and adherence to medical advice”, International Journal of Obesiy, vol/issue: 37(11), pp. 1415-21, 2013.

[24] Bleich, SN., Gudzune, KA., Bennett, WL., Jarienski, M., Cooper, LA., "How does physician BMI impact patient trust and perceived stigma?”, Prev Med., vol/issue: 57(2), pp. 120-4, 2013.

[25] Malterud, K., Ulriksen, K., “Obesity in General Practice”, Scand J Prim Health Care, vol. 28, pp. 205-210, 2010.

[26] Knauss, C., Paxton, SJ., Alsaker, FD., "Relationships amongst body dissatisfaction, internalisation of media body ideal and perceived pressure from media in adolescent girls and boys”, Journal of Body Image, vol. 4, pp.353-360, 2007.

[27] Ogden, J., Andrade, J., Eisner, M., Ironmonger, M., Maxell, J., Muir, E., Siriwardena, R., Thwaites, S., “To treat? To be friend? To prevent? Patients' and GPs' views of the doctor's role”, Scand J Prim Health Care, vol/issue: 15(3), pp. 114-7, 1997.

[28] Kearley, KE., Freeman, GK., Heath, A., "An exproration of the value of the personal doctor-patient relationship in general practice”, British journal of general practice, vol/issue: 51(470), pp. 712-8, 2001.

[29] Van Den Berg, P., Paxton, SJ., Keery, H., Wall, M., Sztainer, DN., "Body dissatisfaction and body comparison with media images in males and females", Journal Of Body Image, vol. 4, pp 257-68, 2007.

[30] Wolf, C., "Physician Assistant Students' attitudes about obesity and obes individuals", The jounal of Physician Assistant Education, vol/issue: 21(4), pp.37-40, 2010.

\section{BIOGRAPHIES OF AUTHORS}

Agustina Arundina Triharja Tejoyuwono is a registered dietitian and has earned her Masters degree in public health majoring nutrition from Gadjahmada University, Indonesia. Her professional career focused on nutritional service and theraphy, public health services, professionalism and ethics. She is the author of "persepsi mahasiswa program studi gizi 


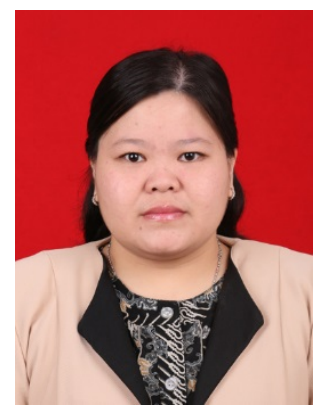

kesehatan terhadap citra tubuh ahli gizi”, published in IJCN at 2011. Currently, she is a lecturer at Medical school of Tanjungpura University and she can be reached through ina.tejo@gmail.com

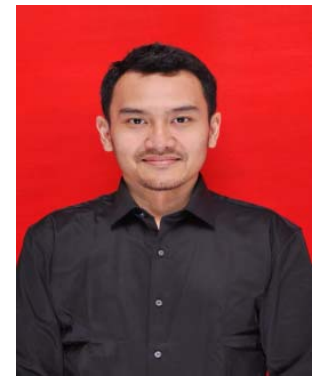

Muhammad Riedha is a registered Medical Doctor who graduated from Faculty of Medicine Universitas Indonesia International Class Program. Riedha was joined in a youth movement called Pencerah Nusantara launched by The Office of President's Envoy in MDGs and spent a year working in rural area called Kecamatan Sikakap in Kabupaten Kepulauan Mentawai, West Sumatra. Working in Mentawai needed broad knowledge of public health area, thus making him a public health enthusiast. Recenty, he works as a lecturer in Faculty of Medicine Universitas Tanjungpura in Pontianak, West Kalimantan as well as Emergency Team in Tanjungpura University Hospital. 